artikel 63 Sr. ${ }^{20}$ Artikel 3 Kaderbesluit 2008/675/JBZ ${ }^{21}$ noopt niet tot een ander oordeel indien het een rechterlijke beslissing betreft die in een andere lidstaat van de Europese Unie is genomen. Dus de in het middel in de onderhavige zaak verdedigde opvatting dat het hof ex art. $63 \mathrm{Sr}$ rekening had dienen te houden met de recente veroordeling van verdachte in België tot levenslange gevangenisstraf t.z.v. o.m. roofmoord gepleegd in dezelfde periode als thans aan de orde zijnde feiten, vond dan ook geen steun in het recht volgens de Hoge Raad. Dat aan verdachte in België levenslange gevangenisstraf is opgelegd, makkte dat niet anders. Dat neemt niet weg dat het de rechter vrijstaat een eerdere, in een andere lidstaat van de Europese Unie uitgesproken veroordeling bij de straftoemeting in aanmerking te nemen, hetgeen het hof dus ook heeft gedaan.

\section{NTS 2020/23}

HR 1 oktober 2019, 18/02394, ECLI:NL:HR:

2019:1448

Zmare mishandeling door ander met sleutel in gezicht te snijden maardoor deze blijvend litteken in gezicht heeft opgelopen, art. 302.1 Sr. Kan opzet op toebrengen zmaar lichamelijk letsel uit de bemijsmiddelen. worden afgeleid?

\section{Aantekening redactie}

Het middel in deze zaak klaagde dat het bewezenverklaarde opzet op het toebrengen van zwaar lichamelijk letsel niet uit de door het hof gebezigde bewijsmiddelen

20. Vgl. HR 31 maart 2009, ECLI:NL:HR:2009:BG9198.

21. '1. Elke lidstaat zorgt ervoor dat in een strafrechtelijke procedure tegen een persoon rekening wordt gehouden met in andere lidstaten tegen de betrokkene uitgesproken, eerdere veroordelingen wegens andere feiten, waarover krachtens de geldende rechtsinstrumenten inzake wederzijdse rechtsbijstand of inzake de uitwisseling van gegevens uit het strafregister informatie is verkregen, zulks voor zover in de lidstaat zelf met eerdere veroordelingen rekening wordt gehouden, en dat aan die in andere lidstaten uitgesproken eerdere veroordelingen rechtsgevolgen worden verbonden, gelijkwaardig aan die welke de nationale wetgeving verbindt aan eerdere veroordelingen in de lidstaat zelf. (...) 5 . Indien het strafbare feit waarover de nieuwe procedure wordt gevoerd, gepleegd is voordat de eerdere veroordeling is uitgesproken of volledig ten uitvoer is gelegd, hebben de leden 1 en 2 niet tot gevolg dat vereist wordt dat lidstaten hun nationale voorschriften betreffende het opleggen van straffen toepassen, wanneer het toepassen van die voorschriften op in een andere lidstaat uitgesproken veroordelingen voor de rechter een beperking zou inhouden bij het opleggen van een straf in de nieuwe procedure. De lidstaten zien er evenwel op toe dat eerdere, in andere lidstaten uitgesproken veroordelingen door rechters in dergelijke gevallen anderszins in aanmerking kunnen worden genomen.' kon worden afgeleid. Ten laste van de verdachte heeft het hof bewezen verklaard dat hij aan het slachtoffer opzettelijk zwaar lichamelijk letsel in de vorm van een blijvend litteken in het gezicht heeft toegebracht door dat slachtoffer met een scherp voormerp in het gezicht te snijden. De verdachte verklaarde - voor zover hier relevant - het volgende:

'Hij wilde mij spreken en mijn moeder deed de deur open. Hij gaf mijn moeder een duw en toen heb ik hem een klets gegeven. Ik had sleutels in mijn handen die was ik vergeten.'

Deze verklaring is door het hof voor het bewijs gebezigd. Het is dus duidelijk dat het juridische punt schuilt in de bewustheid van de aanmerkelijke kans in het kader van voorwaardelijk opzet. Zonder bewustheid van die kans heeft de verdachte immers niet zonder meer de aanmerkelijke kans op zwaar letsel kunnen aanvaarden en kan dus ook niet worden gezegd dat hij dit zware letsel uiteindelijk heeft gewild. Een 'gewone' (harde) klap in het gezicht roept overigens niet zonder meer de aanmerkelijke kans op zwaar letsel in het leven.

Door voor het bewijs niet alleen te gebruiken de verklaring van verdachte dat hij zijn sleutels in zijn hand had, maar ook dat hij 'die was vergeten' heeft het hof volgens de A-G twijfel doen rijzen over het opzet van de verdachte. De Hoge Raad oordeelde echter anders:

'Het Hof heeft tot het bewijs onder meer gebezigd de verklaring van de verdachte "ik had sleutels in mijn handen die was ik vergeten". Het Hof heeft dit onderdeel in zoverre redengevend kunnen achten voor de bewezenverklaring dat het scherpe voorwerp, waarmee de verdachte een stekende beweging heeft gemaakt, een sleutel betrof. Dat het onderdeel "die ik was vergeten" op zichzelf voor de bewezenverklaring niet redengevend is, staat hier, gelet op de bemijsvoering in haar geheel, aan een behoorlijke motivering van de bewezenverklaring niet in de weg.'

Wat bedoelt de Hoge Raad hier met 'de bewijsvoering in haar geheel'? Een ander gebezigd bewijsmiddel was de verklaring van het slachtoffer. Het slachtoffer verklaarde onder meer het volgende:

'Ik zag dat verdachte terug de woning in liep. De deur bleef op een kier staan. Ik weet dat verdachte de keuken ingelopen is want ik hoorde een keukenla hard open en dichtslaan. Ineens hoorde ik de verzorger die nog binnen voor de deur stond roepen: "Niet doen!" Ik zag dat de verzorger de deur probeerde dicht te duwen. Ik was ondertussen al drie meter doorgelopen omdat ik de weg naar mijn werk wilde vervolgen. Ik stond even stil om een telefoontje te plegen. Net voordat ik een straat in wilde lopen, vermoedelijk de [b-straat], zag ik uit mijn ooghoeken verdachte naar mij toe lopen. Ik stond op dat moment met mijn rug naar de woning gericht, met mijn linkerzijde iets naar de woning gedraaid. Ineens zag ik vanuit mijn ooghoeken [verdachte] een stekende 
beweging maken richting mijn bovenlichaam. Met mijn linkerarm probeerde ik hem af te weren maar op dat moment voelde ik een stekend gevoel in mijn gezicht. Ik voelde direct een hoop nattigheid. Ik voelde met mijn hand aan mijn wang en zag vervolgens dat mijn hand onder het bloed zat. Ik zag dat verdachte de woning van zijn moeder inrende.'

Het hof heeft niet bewezen verklaard dat het om een sleutelbos ging. Bewezen is verklaard een scherp voorwerp. De zinsnede dat de verdachte zijn sleutels in zijn handen had levert daarvoor bewijs op (hij geeft toe iets in zijn handen te hebben gehad). Nu niet is komen vast te staan dat het letsel met sleutels is toegebracht en de verdachte iets scherps uit de keukenla heeft gepakt, kan niet worden gezegd dat het hof bij zijn oordeel over het voorwaardelijk opzet is uitgegaan van de situatie dat het letsel is toegebracht met een sleutelbos waarvan de verdachte zich niet bewust was dat hij die vasthad. 